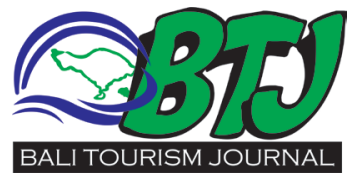

\title{
Polemic of Indonesian Criminal Code Bill on Bali's Tourism Industry
}

\author{
I Made Ari Kapela ${ }^{1}$
}

\section{ABSTRACT}

Indonesian Criminal Code Bill proposal, suddenly became a hot issue after Indonesia commemorate their 74th Independence Day. The executive and legislative accelerated completion of Indonesian Criminal Code Bill (ICCB) at Fairmont Hotel, Jakarta. Many parties have been urging the government to revise some outdated articles since the penal code was a product of Dutch colonialism in the past. Three crucial topics were discussed and added to the draft regarding blasphemy to president, crimes against morality and decency, as well as specific intent crime. Apparently, some parties were unsatisfied with the draft. Waves of uproar sprang up between mid-September and early October 2019. the demonstrators considered that there are ten controversial articles in the ICCB that have vague enforcement parameters. To reduce the public tension, the government agreed to delay the ICCB ratification that, according to public includes multiple problematic articles. President Joko Widodo stated that more input would be conducted before disseminate the latest ICCB information to public. The postponement would be evoked after the new set of parliaments is inaugurated. Albeit being postponed, Tourism practitioner in Bali experiencing significant loss of tourists visit due to the issues. It is expected in future; the government would involve tourism practitioner in group discussion before setting new regulations that may affect the vital industry of Indonesia.

Keyword: Indonesian Criminal Code Bill, Tourism Industry

Cite This Article: Kapela, I.M.A. Polemic of Indonesian Criminal Code Bill on Bali's Tourism Industry. Bali Tourism Journal (BTJ)2019, 3 (1): 34-37.

1PT. Charoen Pokphand Indonesia kadek.arix@gmail.com

\section{Editor:}

Ida Bagus Ngurah Tri Pramana
Received : 2019-08-26 Accepted : 2019-09-10 Published: $2019-09-25$

\section{INTRODUCTION}

Indonesian Criminal Code Bill proposal, suddenly became a hot issue after Indonesia commemorate its $74^{\text {th }}$ Independence Day. In 2019, the country is facing multiple problems that make the public restless; from thick smog resulted from the forest fire, anti-corruption code revision proposal, ethnicity conflict in Surabaya as well as riot in Papua, and the recent upheaval of penal code revision proposal. Media are publishing multiple news with countless debate whether the bill should be passed into law or not. Some argue it is highly urgent to legalise the bill since relating matters have not been regulated for a long time.

On the other hand, some view the draft content is poorly constructed and might be easily manipulated due to its vague parameter. Tourism practitioner in Bali also proclaimed their critiques to the bill that has potential to disturb the tourism industry in Indonesia. Then, what are the contents of the controversial articles in the Criminal Code Bill which are considered problematic and ignite thousands of student demonstrations in various cities?

\section{COLONIAL PENAL CODE REVISION}

On 15 September 2019, The executive and legislative accelerated completion of Indonesian Criminal Code Bill (ICCB) at Fairmont Hotel, Jakarta. ICCB plan is not a new issue in the country since many parties have been urging the government to revise some articles that no more relevant since the penal code was a product of Dutch colonialism in the past. Three crucial topics were discussed and added to the draft regarding blasphemy to president, crimes against morality and decency, as well as specific intent crime. Initially, The Head of the Presidential Staff Office, Moeldoko gave deadline to the task force to finalise the draft until the end of August 2019 after it passed its consignment stages from 25 to 26 June 2019. Later, the draft manuscript was freely distributed through internet. Apparently, some parties were unsatisfied with its content. ${ }^{1}$

Soon after the draft distribution, 40 NGO formed National Alliance for Criminal Code Reform. They rated the discussion as 'sneaky' and included problematic articles. ${ }^{2}$

A wave of uproar sprang up between midSeptember and early October 2019. The outcry students and NGOs urged that the ICCB legalisation must be stopped at once. Including the revision of the Corruption eradication commission code, which in their opinion weakening the anticorruption institution. Regarding the ICCB, the demonstrators pointed out ten controversial articles 


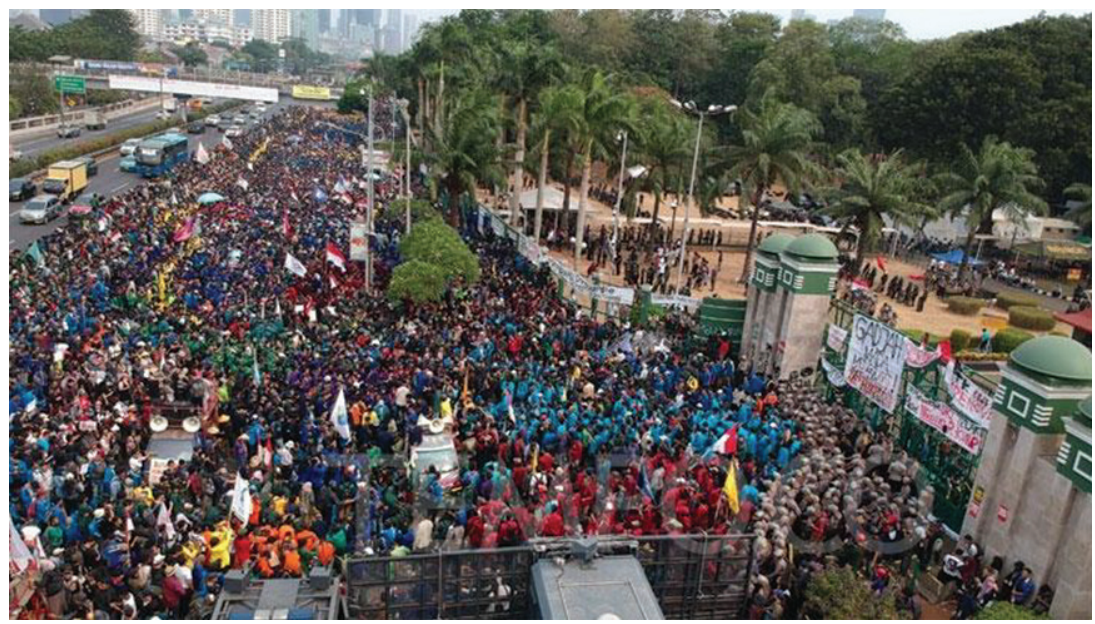

Figure 1. The outcry students and NGOs urged that the ICCB legalisation must be stopped at once. ${ }^{3}$

in the ICCB with vague enforcement parameters. There are:

1. Article 67, Article 99, Article 100, Article 101 RKUHP, regarding the death penalty

2. Article 167 RKUHP draft 28 August 2019 concerning treason arrangements

3. Articles 218-219 of the Indonesian Criminal Code, concerning blasphemy to the president. Article 240-241 of the Indonesian Criminal Code (RKUHP) about insulting the legitimate government Article 353-354 of the Indonesian Criminal Code (RKUHP) about contempt of Public Power / State Institutions

4. Article 304 RKUHP concerning Crimes Against Religion

5. Article 417 paragraph (1) concerning extramarital sex.

6. Articles 414-415 draft KUHP draft August 28, 2019, about contraception

7. Article 470 to 472 RKUHP draft 28 August 2019 concerning abortion

8. Articles 604-607 of the Criminal Code Code concerning corruption

9. Articles 599-600 of the Criminal Code Code concerning violations of human rights

10. Article 188 concerning the teachings of Communism or Marxism - Leninism ${ }^{4}$

\section{GOVERNMENT'S RESPONSE}

The outcry escalated in various provinces, demanding the central government to postpone the ratification process. After perilous hearing and discussion, President Joko Widodo on Friday, 20 September 2019, through Minister of Justice and Human Rights, Yasonna Laoly, formally asked the parliament to delay the ratification. He expressed, it would be passed into law on the next set of upcoming new parliament members. "More input will be required" He added to the press. ${ }^{5}$

Indonesia Minister of Law and Human Rights, Yasonna Laoly admitted there were differences of opinion between President Joko Widodo and the parliaments regarding the postponement of ICCB. The House of Representatives suggested the Criminal Code Bill be passed in this period, he said. The pledge was conveyed by the head of house representative in a meeting with President Jokowi on Monday, 23 September afternoon. However, the government preferred they would like to explore it further before disseminating the information to the public. The official meeting with the house of representative was held on Tuesday, September 24, 2019. ${ }^{7}$ Head of house of representatives, Bambang Soesatyo officially agreed to delay ratification of ICCB. It would be postponed until an unspecified time to reduce public tension, he said. ${ }^{8}$ The new House of Representatives was inaugurated on Tuesday, 1 October 2019. After inauguration, it is said the top most priority they should discuss are five controversial draft laws and ICCB. ${ }^{9}$

\section{IMPACT ON TOURISM AND HOSPITALITY INDUSTRY}

Tourism and hospitality practitioners in Bali officially reject the proposed ICCB due to many articles have the potential to disrupt the tourism industry on the Island. The response was conveyed by the Head of the Bali Regional Tourism Promotion Board, Tjokorda Oka Artha Ardana Sukawati or Cok Ace. He supported President Joko Widodo's decision to request the House of Representatives to postpone the ratification of ICCB. According to Cok Ace, they submitted official letter of rejection highliting several articles that might be detrimental to Bali's tourism. Some articles which provisionally proposed for review are extramarital sex law, and living law due to these articles, in its implementation, will inevitably violate the tourist's privacy. ${ }^{11,12}$

In Article number 417, there is a regulation that prohibits copulation between unmarried couple, with a maximum of one-year imprisonment or category II fines. Additionally, article 419 prohibits unmarried couples, to live together. The punishment can be jailed for a maximum of six months or a category II fine, worth around IDR 50 million. ${ }^{14}$

Melbourne University professor, Tim Lindsey, who also serves as Director of the Center for Indonesia Law, Islam and Society, views extramarital sex law would create significant problems for foreigners if they were imposed. It 


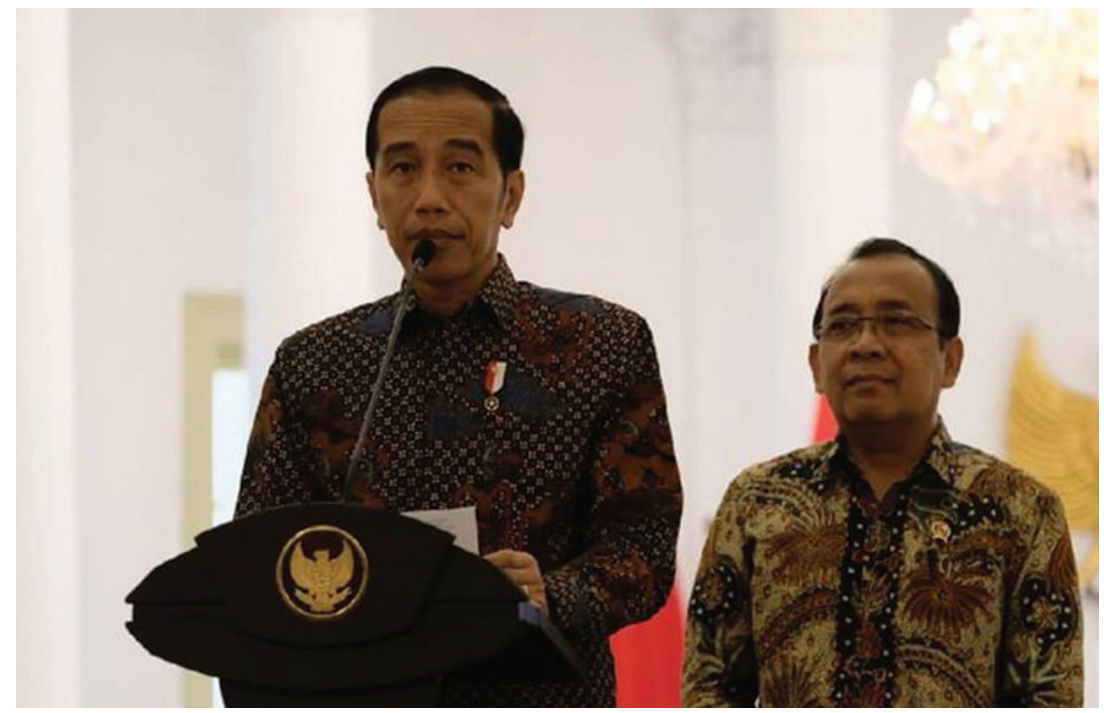

Figure 2. President Joko Widodo

might be possible for an irresponsible officer to blackmailed any foreigner who enjoys their stay in Bali. "Do (foreign) tourists have to carry a marriage certificate when visiting Indonesia?" Lindsey added. He certainly not surprising that representatives of foreign countries in Indonesia, including Australia, would renew travel advice to their citizen before deciding to spend their vacation in Indonesia.

Moreover, Researcher at the International Institute for Strategic Studies, Aaron Conolly in Singapore, said the change in the law would have a significant impact on tourism in Bali and other regions in Indonesia. These days, the Indonesian government is actively promoting new tourist destinations to encourage tourism growth. "Representatives of European countries in Jakarta privately informed the members of the House of Representatives that they would carry out an update on the travel warning and there might be resulted in unpleasant media coverage" He revealed. However, the suggestion was ignored. In his opinion, Conolly suspected the legislators did not fully understand the consequences. Although the law will primarily not be applied to foreigners, it will affect the tourism sector. ${ }^{5}$

From the tourism industry perspective, the Indonesian Hotel and Restaurant Association (PHRI) revealed a surprising report. Since the polemic of ICCB, there have been reports of foreign tourists, including Australia cancelling their visits specifically to Bali and diverting itinerary to Thailand. The Provincial Government of Bali immediately responded the report. Head of the Bali Tourism Office, Putu Astawa said this condition is detrimental and must be addressed immediately,

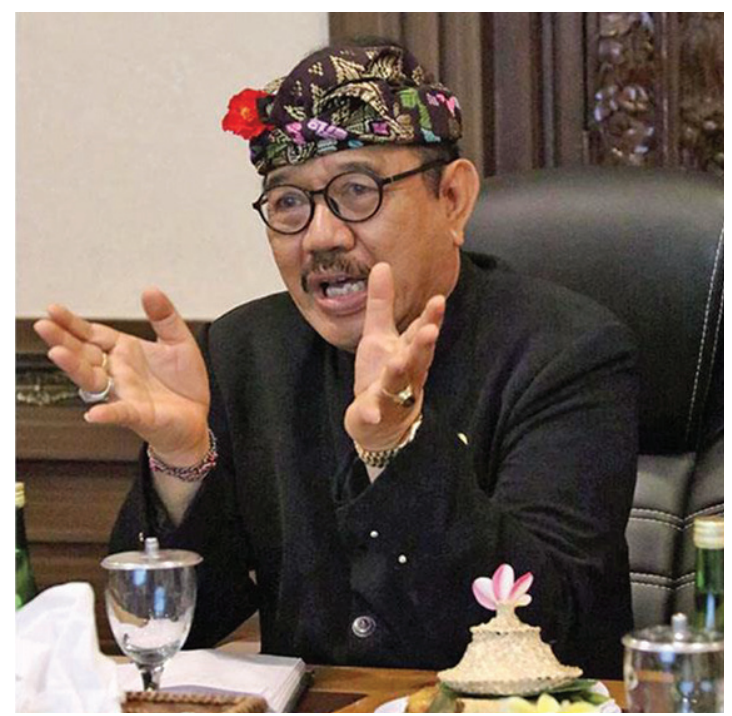

Figure 3. Tjokorda Oka Artha Ardana Sukawati supported President Joko Widodo's decision to request the House of Representatives to postpone the ratification of ICCB. ${ }^{10}$

or competitors in Southeast Asia would seize the chance. Thailand, Malaysia, Singapore and Vietnam are currently known to offer other exotic destinations that rival to Bali tourism. PHRI Deputy Chairman Sudrajat said that since the ICCB uproar, many of his members received cancellations from foreign clients. The clients prefer to move to Thailand. He regretted, instead of being hastily completed the draft, it would be a wise movement should the government involve tourism and hospitality practitioners in focus group discussion beforehand. PHRI Bali added, that there might be some articles that poorly covered by foreign media that may result in misconception in foreign public. Giving rise to negative perceptions from other countries, especially about privacy issues in Bali. ${ }^{14}$

\section{CONCLUSION}

To reduce the public tension, the government agreed to delay the ICCB ratification that, according to public includes multiple problematic articles. President Joko Widodo stated that more input would be conducted before disseminate the latest ICCB information to public. The postponement would be evoked after the new set of parliaments is inaugurated. Albeit being postponed, Tourism practitioner in Bali experiencing significant loss of tourists visit due to the issues. It is expected in future; the government would involve tourism practitioner in group discussion before setting new 


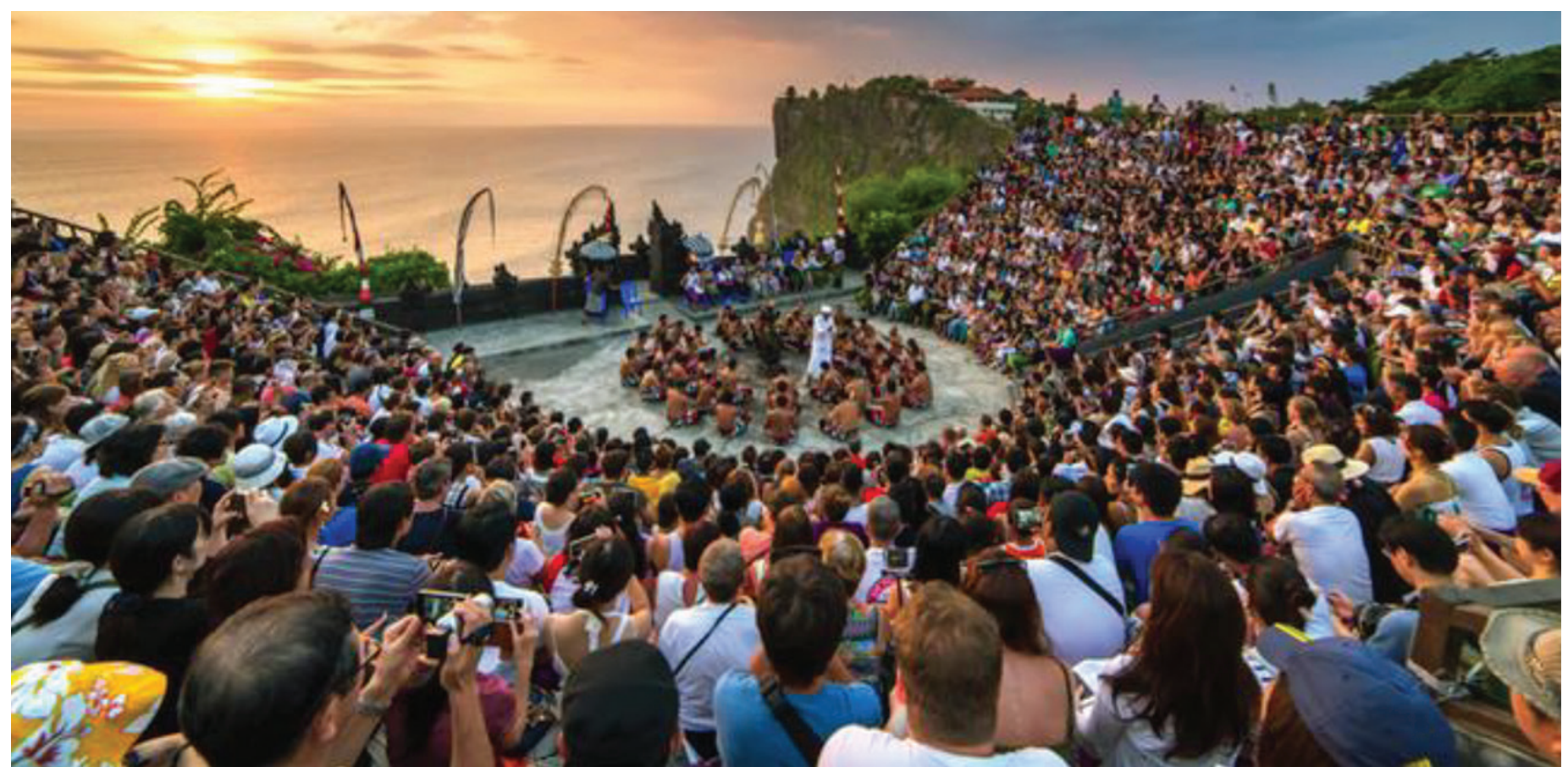

Figure 4. The Indonesian government is actively promoting new tourist destinations to encourage tourism growth.

regulations that may affect the vital industry of Indonesia.

\section{REFERENCES:}

1. I Umbari. Istana Beri Waktu Pembahasan RKUHP Rampung Akhir Agustus 2019. Liputan6[dot]com. 2019. Available at URL: https://www.liputan6.com/news/ $\mathrm{read} / 4038034 /$ istana-beri-waktu-pembahasan-rkuhprampung-akhir-agustus-2019

2. A M Idhom. Isi RUU KUHP dan Pasal Kontroversial Penyebab Demo Mahasiswa Meluas. Tirto[dot\}id. 2019. Available at URL: https://tirto.id/isi-ruu-kuhp-dan-pasalkontroversial-penyebab-demo-mahasiswa-meluas-eiFu

3. Image by Subekti Taken from "Penundaan RUU KUHP, Mahasiswa Demo ke DPR: Jokowi Bermain Gimmick". Tempo. 2019. Available at URL: https://metro.tempo.co/ read/1251819/penundaan-ruu-kuhp-mahasiswa-demo-kedpr-jokowi-bermain-gimmick

4. H B Fisandra. Disahkan Pekan Depan, Ini 10 Pasal Kontroversial RKUHP. Tempo. 2019. Available at URL: https://nasional.tempo.co/read/1248284/disahkan-pekandepan-ini-10-pasal-kontroversial-rkuhp/full\&view=ok

5. S Agmasari. Turis Asing Mungkin Tak Akan Kembali ke Indonesia karena RKUHP. Travel Kompas. 2019. Available at URL: https://travel.kompas.com/ $\mathrm{read} / 2019 / 09 / 23 / 092141927 /$ turis-asing-mungkin-takakan-kembali-ke-indonesia-karena-rkuhp?page=all.

6. Image by A Prasetia "Jokowi Minta Pengesahan RUU KUHP Ditunda!”. Detik[dot]com. 2019. Available at URL: https://news.detik.com/berita/d-4714439/jokowi-mintapengesahan-ruu-kuhp-ditunda

7. B U Putri. Jokowi Minta RKUHP Ditunda, DPR Ingin Jalan Terus. Tempo. 2019. Available at URL: https://nasional. tempo.co/read/1251506/jokowi-minta-rkuhp-ditundadpr-ingin-jalan-terus/full\&view $=$ ok

8. H P Sari. Ketua DPR: RKUHP Ditunda sampai Waktu yang Tak Ditentukan. Kompas. 2019. Available at URL: https://nasional.kompas.com/read/2019/09/25/06254461/ ketua-dpr-rkuhp-ditunda-sampai-waktu-yang-takditentukan?page $=$ all.

9. Anonymous. RUU KUHP: Beban berat DPR baru melanjutkan tugas anggota dewan sebelumnya. BBC. 2019. Available at URL: https://www.bbc.com/indonesia/ indonesia- 49878488

10. Image taken from Bali Travel News "Sejumlah Pasal RKUHP Dinilai Rugikan Pariwisata Bali Apa Saja?”. 2019. Available at URL: https://bali-travelnews.com/2019/09/23/ sejumlah-pasal-rkuhp-dinilai-rugikan-pariwisata-baliapa-saja/

11. Anonymous. Bali Tolak RKUHP, Sejumlah Pasal Dinilai Ganggu Kepariwisataan. Tempo. 2019. Available at URL: https://bisnis.tempo.co/read/1250958/bali-tolak-rkuhpsejumlah-pasal-dinilai-ganggu-kepariwisataan

12. A Mardiastuti. BPPD Bali Ajukan Revisi Pasal RKUHP yang Dinilai Ganggu Pariwisata. Detik[dot]com. 2019. Available at URL: https://news.detik.com/berita/d-4717417/bppdbali-ajukan-revisi-pasal-rkuhp-yang-dinilai-ganggupariwisata?single $=1$

13. Image taken from $\mathrm{CNN}$ Indonesia "Jumlah Wisatawan Mancanegara di Bali Melonjak”. 2017. Available at URL: https://www.cnnindonesia.com/gayahidup/20170908153004-307-240401/jumlah-wisatawanmancanegara-di-bali-melonjak

14. Anonymous. RKUHP Bikin Turis Batal ke Bali Pindah ke Thailand, Bali Rugi. CNBC. 2019. Available at URL: https://www.cnbcindonesia.com/news/201909260839154-102321/rkuhp-bikin-turis-batal-ke-bali-pindah-kethailand-bali-rugi

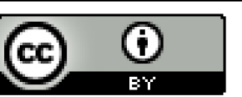

This work is licensed under a Creative Commons Attribution 